\section{A study to examine the role of environmental motivation and sensation seeking personality to predict behavioral intention in volunteer tourism}

\author{
Suhud, Usep $\bowtie$ \\ Faculty of Economics, Universitas Negeri Jakarta, Indonesia (usepsuhud@feunj.ac.id)
}

Received: 8 August 2014

Available Online: 17 November 2014
Revised: 13 November 2014 DOI: $10.5861 /$ ijrse.2014.907

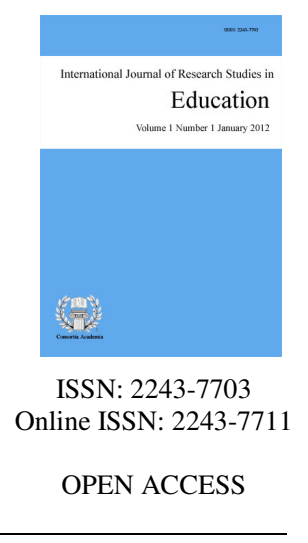

\title{
Abstract
}

The first, objective of this study is to understand the role of environmental motivation and sensation seeking personality in predicting intention to be involved in VT. The second objective is to examine whether the theory of reasoned action could be extended by adding two new variables - environmental motivation and sensation seeking personality. The last objective is to understand the difference intention in difference periods of time - within one, three, and five years; Volunteer tourism is about combination of volunteering and tourism activities that require participants to pay their own costs - transport, accommodation, meals, and even contribute to the project offered in a destination. Researchers claimed that there is an overlap between volunteer tourism and eco-tourism. This claim referred to two reasons: most of projects are relating to environment and part of motivations of the participants relate to environment. The author adapted the theory of reasoned action by adding new variables sensation seeking personality and environmental motivation. The author considers that this is an experimental study as there has not been documented that a single environmental motivation has an influence on behavioral intention, particularly in the tourism field. The author collected data using an online survey and approached volunteers, tourists, and volunteer tourists to participate in an online survey conveniently. In total, 551 respondents participated, coming from developed and developing countries. Data were analyzed using exploratory and confirmatory factor analyses (structural equation model). Three fitted models were built representing intention within one year, three years, and five years. Almost all hypotheses in all models were accepted. This quantitative study proves that environmental motivation and sensation seeking personality have different influences on intention to be involved in VT in different periods of time. In addition, it shows that theory of reasoned action can be extended by adding new variables - environmental motivation and sensation seeking personality variables.

Keywords: volunteer tourism; volunteer tourists; environmental motivation; sensation seeking personality; theory of reasoned action; structural equation model 


\section{A study to examine the role of environmental motivation and sensation seeking personality to predict behavioral intention in volunteer tourism}

\section{Introduction}

The theory of reasoned action (Ajzen \& Fishbein, 1980; Fishbein \& Ajzen, 1975) and the extension versions have been applied by prior researchers in tourism and volunteerism studies. However, there is a gap in volunteer tourism field in using this theory. Therefore, the objective of this study is to explore the role of environmental motivation in predicting a person's intention to be involved in volunteer tourism (VT). The author extended the theory of reasoned action by adding environmental motivation in the proposed model. Some researchers claimed that volunteer tourism has a link to eco-tourism (Brightsmith, Stronza, \& Holle, 2008; Coghlan, 2006; Galley \& Clifton, 2010; Gray \& Campbell, 2007; Van der Meer, 2007). Unfortunately, most of these researchers took a qualitative approach to answer the phenomenon.

This study offers a quantitative approach that is addressed to understand issues as follow:

1. The role of environmental motivation and sensation seeking personality in predicting intention to be involved in VT;

2. Whether the theory of reasoned action could be extended by adding two new variables environmental motivation and sensation seeking personality.

3. The difference intention in difference periods of time - within one, three, and five years;

\section{Literature review}

As limited researchers who conducted studies on VT using quantitative approach, the author initiated to adapt theories from tourism, volunteerism, and volunteer tourism fields.

\subsection{Subjective norms}

According to prior studies in tourism and leisure (for example, Hrubes, Ajzen, \& Daigle, 2001; Lam \& Hsu, 2006; Shen, Schuttemeyer, \& Braun, 2009; Wu \& Teng, 2011), subjective norms may influence intention. These studies led to the following hypothesis of this research:

H1 - There is a positive relationship between a person's subjective norms and their intention to be involved in VT.

The subjective norms variable was measured by three items adapted from Greenslade and White's (2005) study. Respondents were asked to assess the sensation-seeking scale using a seven-point Likert's scales, 1 for extremely inaccurate to 7 for extremely accurate. The items of subjective norms are as follow:

$>\quad$ Most people who are important to me would NOT want me to be engaged in volunteer tourism.

Most people who are important to me would approve of my engaging in volunteer tourism.

$>\quad$ Most people who are important to me would think it was desirable for me to be engaged in volunteer tourism.

\subsection{Attitude towards VT concept}

Studies in tourism and recreation conducted by Hrubes, Ajzen, and Daigle (2001), Lam and Tsu (2006), and 
The role of environmental motivation and sensation seeking personality to predict behavioral intention

Brown (1999) reported that attitude may influence intention. Furthermore, Tsai (2010) showed a link between attitude and motivation. These studies led to the following hypotheses:

$\mathrm{H} 2 \mathrm{a}$ - There is a positive relationship between a person's attitude towards the concept of VT and their motivation to be involved in VT.

H2b - There is a positive relationship between a person's attitude towards the concept of VT and their intention to be involved in VT.

Seven items were used to measured attitude. Respondents were asked their opinion about the following definition of the concept of VT: Volunteer tourism is a combination of volunteer and tourism activities at a travel destination. This often requires a participant to pay some or all costs involved, such as transport, accommodation, meals, and possibly some financial contribution to the actual project (Broad \& Jenkins, 2008; Hobbs, 2007; Raymond, 2008; Tourism Research and Marketing, 2008; Wearing, 2001). Seven-option bipolar semantic scales from Han, Lee, and Lee (2011) were provided. Intentionally, the items were presented in a different order. Some items were ordered in in positive-negative value formations; others were negative-positive value formations. The items of attitude on the concept of VT as follows:

$\begin{array}{ll}> & \text { Enjoyable }- \text { unenjoyable } \\ > & \text { Invaluable }- \text { valuable } \\ > & \text { Uninteresting }- \text { interesting } \\ > & \text { Desirable }- \text { undesirable } \\ > & \text { Unpleasant }- \text { pleasant } \\ >\quad \text { Unforgettable }- \text { forgettable } \\ \end{array}$

\subsection{Environmental motivation to be involved in VT}

Studies in tourism show an impact of motivation on intention as reported by Huang and Hsu (2009), Jang et al. (2009), and Konu and Laukkanen (2009). These studies led to the following hypothesis:

H3 - There is a positive relationship between a person's motivation to be involved in VT and their intention to be involved in VT.

In his study, Suhud (2013) proved his thesis that motivation in VT consisted of taking/receiving and giving motivations and environmental motivation is part of giving motivations. Environmental motivation to be involved in VT was measured by indicators that have been used by Bruyere and Rappe (2007). Respondents were asked to assess their environmental motivations using a seven-point Likert's scale: 1 for extremely unimportant through to 7 for extremely important. The items used for the motivation construct were:

$>$ Sub-dimension: environmental motivations

$>\quad$ I have a concern for the environment.

$>$ Volunteer tourism would allow me to help the environment.

\subsection{Sensation-seeking personality}

A study undertaken by Wymer, Self, and Findley (2008) showed that there was a relationship between the sensation-seeking personality and intention. Other studies in tourism conducted by $\mathrm{Xu}(2010)$ and $\mathrm{Xu}$ et al. (2010) reported that sensation-seeking personality influenced motivation. The studies above led to the following hypotheses:

H4a - There is a positive relationship between a person's sensation-seeking personality and their motivation to be involved in VT. 
Suhud, U.

H4b - There is a positive relationship between a person's sensation-seeking personality and their intention to be involved in VT.

Sensation-seeking personality was measured using the Brief Sensation Seeking scale adopted from Wymer Jr. et al. (2010). The item "I like to do frightening things" was changed to "I like to do adventurous things" were asked to assess the sensation-seeking scale using a seven-point Likert scale, 1 for extremely disagree to 7 for extremely agree. The items of sensation-seeking personality as follows:

\section{Experience seeking}

$>\quad$ I would like to explore strange places.

$>\quad$ I get restless when I spend too much time at home.

\section{Disinhibition}

$>\quad$ I like to do adventuring things.

$>\quad$ I like wild parties.

\section{Boredom susceptibility}

$>\quad$ I would like to take off on a trip with no pre-planned routes or timetables.

$>$ I prefer friends who are excitingly unpredictable.

\section{Thrill and adventure seeking}

$>$ I would love to have new and exciting experiences, even if they are illegal.

$>\quad$ I would like to try bungee jumping.

\subsection{Intention to become involved in VT}

The intention was measured using the probability scale (Juster, 1966) which has been adopted and/or adapted by prior researchers in tourism, media consumption, and marketing (for example, Franke, Keinz, \& Steger, 2009; Holmes \& Yan, 2012; Kerr, Cliff, \& Dolnicar, 2012; Nguyen \& Romaniuk, 2012). Respondents were asked to assess their intentions to become involved in VT within 1 year, 3 years, and 5 years. The scale options were as follows:

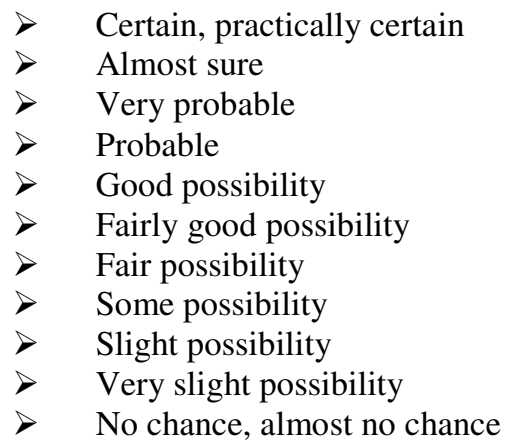

\subsection{Hypotheses and the proposed model}

The table below indicates links between one variable and another. Based on the literature review above, in total there are six links, including a link between subjective norms and behavioral intention (H1), attitude and behavioral intention ( $\mathrm{H} 2 \mathrm{a})$, attitude and motivation $(\mathrm{H} 2 \mathrm{~b})$, motivation and behavioral intention ( $\mathrm{H} 3)$, sensation seeking personality and motivation ( $\mathrm{H} 4 \mathrm{a})$, and sensation seeking personality and behavioral intention (H4b). The table also shows total of six hypotheses. 
The role of environmental motivation and sensation seeking personality to predict behavioral intention

Table 1

Hypotheses of this study

\begin{tabular}{|c|c|c|c|c|c|}
\hline $\begin{array}{l}\text { Independent } \\
\text { variable }\end{array}$ & & $\begin{array}{l}\text { Dependent } \\
\text { variable }\end{array}$ & Tendency & Hypothesis & Supported theories \\
\hline Subjective norms & $\rightarrow$ & $\begin{array}{l}\text { Behavioral } \\
\text { intention }\end{array}$ & + & $\mathrm{H} 1$ & $\begin{array}{l}\text { Wu and Teng (2011), } \\
\text { Hrubes et al. (2001), } \\
\text { Lam and Hsu (2006) }\end{array}$ \\
\hline Attitude & $\rightarrow$ & $\begin{array}{l}\text { Environmental } \\
\text { motivation }\end{array}$ & + & $\mathrm{H} 2 \mathrm{a}$ & Tsai (2010) \\
\hline Attitude & $\rightarrow$ & $\begin{array}{l}\text { Behavioral } \\
\text { intention }\end{array}$ & + & $\mathrm{H} 2 \mathrm{~b}$ & $\begin{array}{l}\text { Hrubes et al. (2001), Shen et al. (2009), } \\
\text { (Lam \& Hsu, 2006), } \\
\text { Wu and Teng (2011) }\end{array}$ \\
\hline Motivation & $\rightarrow$ & $\begin{array}{l}\text { Behavioral } \\
\text { intention }\end{array}$ & + & H3 & $\begin{array}{l}\text { Huang and Hsu (2009), } \\
\text { Konu and Laukkanen (2009) }\end{array}$ \\
\hline $\begin{array}{l}\text { Sensation seeking } \\
\text { personality }\end{array}$ & $\rightarrow$ & Motivation & + & $\mathrm{H} 4 \mathrm{a}$ & Xu (2010), Xu et al. (2010) \\
\hline $\begin{array}{l}\text { Sensation seeking } \\
\text { personality }\end{array}$ & $\rightarrow$ & $\begin{array}{l}\text { Behavioral } \\
\text { intention }\end{array}$ & + & $\mathrm{H} 4 \mathrm{~b}$ & Wymer Jr. et al. (2008) \\
\hline
\end{tabular}

Furthermore, the links as mentioned on the table are installed all together on a figure forming a full model as illustrated below. This proposed model is to be tested in the data analysis using structural equation modelling.

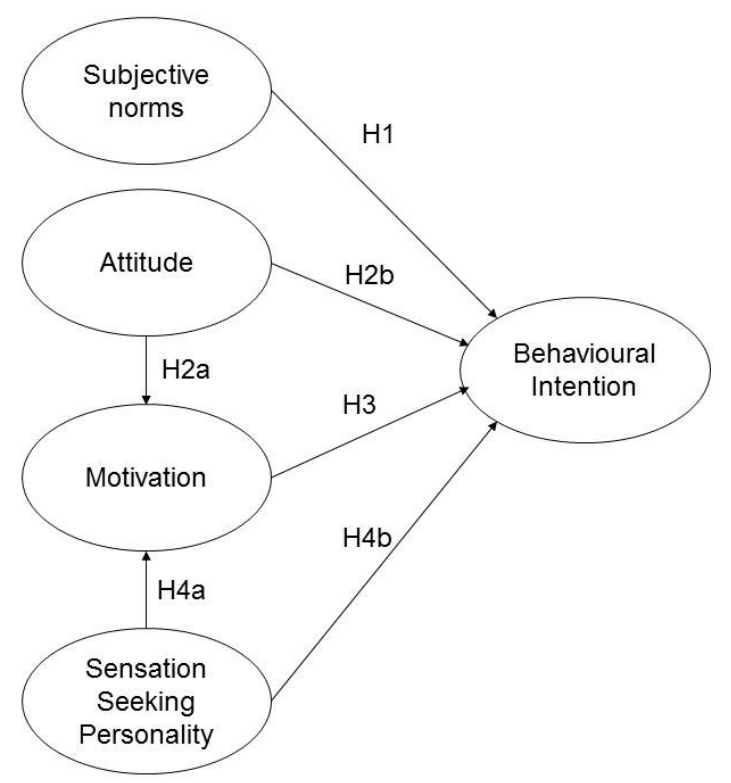

Figure 1. The proposed model

\section{Methods}

To collect the data, the author used a web-based survey and the questionnaire was developed using the Qualtrics survey web service. Potential respondents were attracted using personal and group communication techniques via emails and social media messages. A total of 551 respondents were recruited and completed the survey. The percentages of male and female participants were accidently 50\% (275) and 50\% (276) respectively.

\subsection{Nationality}

A total of $390(71 \%)$ respondents were citizens of developed countries, such as Australia, Austria, Canada, France, Germany, Greece, Iceland, Ireland, Italy, Japan, New Zealand, Spain, Taiwan, the United Kingdom, and the United States. One respondent held a citizenship of a former country - ex-Yugoslavia. Moreover, 161 (29\%) respondents were citizens of developing countries, such as Algeria, Argentina, Belarus, Brazil, China, Columbia, 
Suhud, U.

Costa Rica, Ghana, Iceland, India, Indonesia, Iran, Iraq, Kenya, Macedonia, Malaysia, Nigeria, Philippines, Poland, Romania, Russian Federation, South Africa, Sri Lanka, Sudan, Thailand, Vanuatu, and Vietnam.

\subsection{Country of residence}

Approximately 499 (83\%) of respondents resided in developed countries, such as Australia, Iceland, Italy, Japan, New Zealand, Singapore, Spain, United Arab Emirates, United Kingdom, and United States. Respondents who resided in Australia (78\%) were predominant. Furthermore, 92 (17\%) respondents resided in developing countries, such as Argentina, China, India, Indonesia, Iran, Macedonia, Malaysia, Philippines, Poland, Sri Lanka, Thailand, Vanuatu, and Yugoslavia.

\subsection{Age group}

The age range of respondents was from 18 to 71 years. In general, the age groups were evenly distributed, particularly those aged between 24 - 47 years (between 14\% and 18\%). Respondents aged 30 - 35 years were the highest category (18\%).

\subsection{Level of education}

The largest aggregate was those who had achieved the postgraduate level (44\%). Respondents with undergraduate levels were in the second largest group (36\%), whereas those who had less than high school levels of education were a very small group, comprising only $0.4 \%$ of the total sample.

\subsection{Marital status}

Married (and de facto) respondents comprised $63 \%$ of the sample, with singles $30 \%$; the remaining respondents were divorced $(5 \%)$, separated $(2 \%)$, and widowed $(0.4 \%)$.

\subsection{Employment status}

Respondents were able to indicate if they were undertaking combine activities such as study and working part time. The frequencies of respondents were 'employed for wages' - 64\%, 'self-employed' - 23\%, and 'a student' - 19\%, with the remaining stating that they were: 'out of work and looking for work' (4.4\%), 'out of work but not currently looking for work' $(1 \%)$, 'in a gap year' $(0.7 \%)$, 'retired' $(0.7 \%)$, and 'unable to work' $(0.4 \%)$.

\section{Findings}

\subsection{Confirmatory factor analysis}

As subjective norm and environmental motivation only had three indicators each, these variables were not tested in exploratory factor analysis. The author focussed on attitude towards the concept of VT and sensation seeking personality variables. Results of confirmatory factor analysis on attitude retained five indicators, including AT1, AT2, AT3, AT5, and AT7, whereas AT5 and AT7 were inter-correlated. This construct had probability of 0.450, CMIN/DF of 0.922 , CFI of 1.000 , and RMSEA of 0.000 .

Furthermore, confirmatory factor analysis result of sensation seeking personality resulted two dimensions excite seeking and new experience seeking) and significant with a study undertaken by Suhud (2014). The construct produced probability of 0.435 , CMIN/DF of 0.910 , CFI of 1.000, and RMSEA of 0.000 . The construct survived four indicators (SS7 and SS6 for the first factor, and SS1, SS3, and SS2, for the second factor). This construct is completely different with the Brief of Sensation Seeking (BSS), the one that established by Wymer Jr. et al. (2010). These researchers mentioned that BSS consists of four dimensions including experience seeking, 
The role of environmental motivation and sensation seeking personality to predict behavioral intention disinhibition, boredom susceptibility, and thrill and adventure seeking.

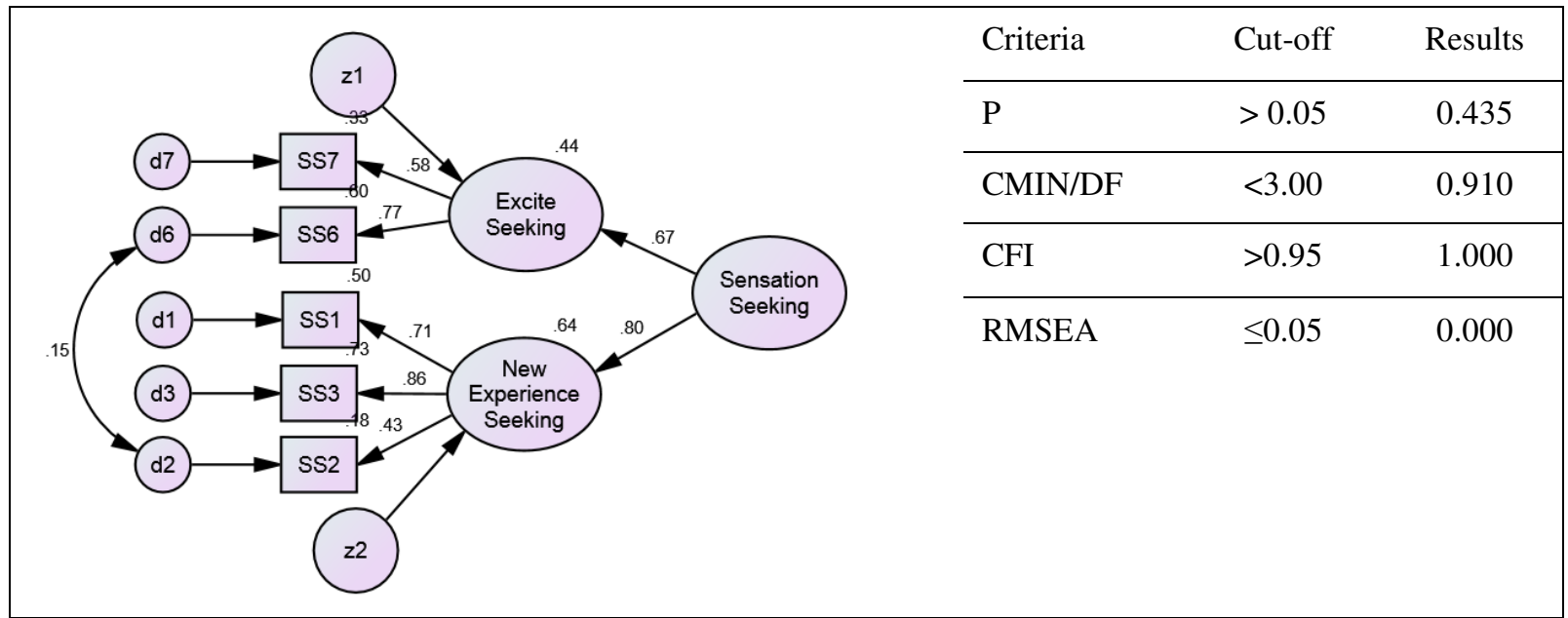

Figure 2. The results of confirmatory factor analyses of attitude and sensation seeking personality variables

All these variables, including subjective norm, attitude, environmental motivation, and sensation seeking then were put all together in the full model as proposed to examine whether the model could work to achieve the research objectives.

\subsection{The proposed model testing}

The author modified the proposed model became three separated models. Each model was to test intention to be involved in VT within three different period of time - one year, three years, and five years.

\section{Intention within one year}

The fitted model of intention within one year was achieved with probability of 0.098, CMIN/DF of 1.229, CFI of 0.994, and RMSEA of 0.020 (see the figure below).

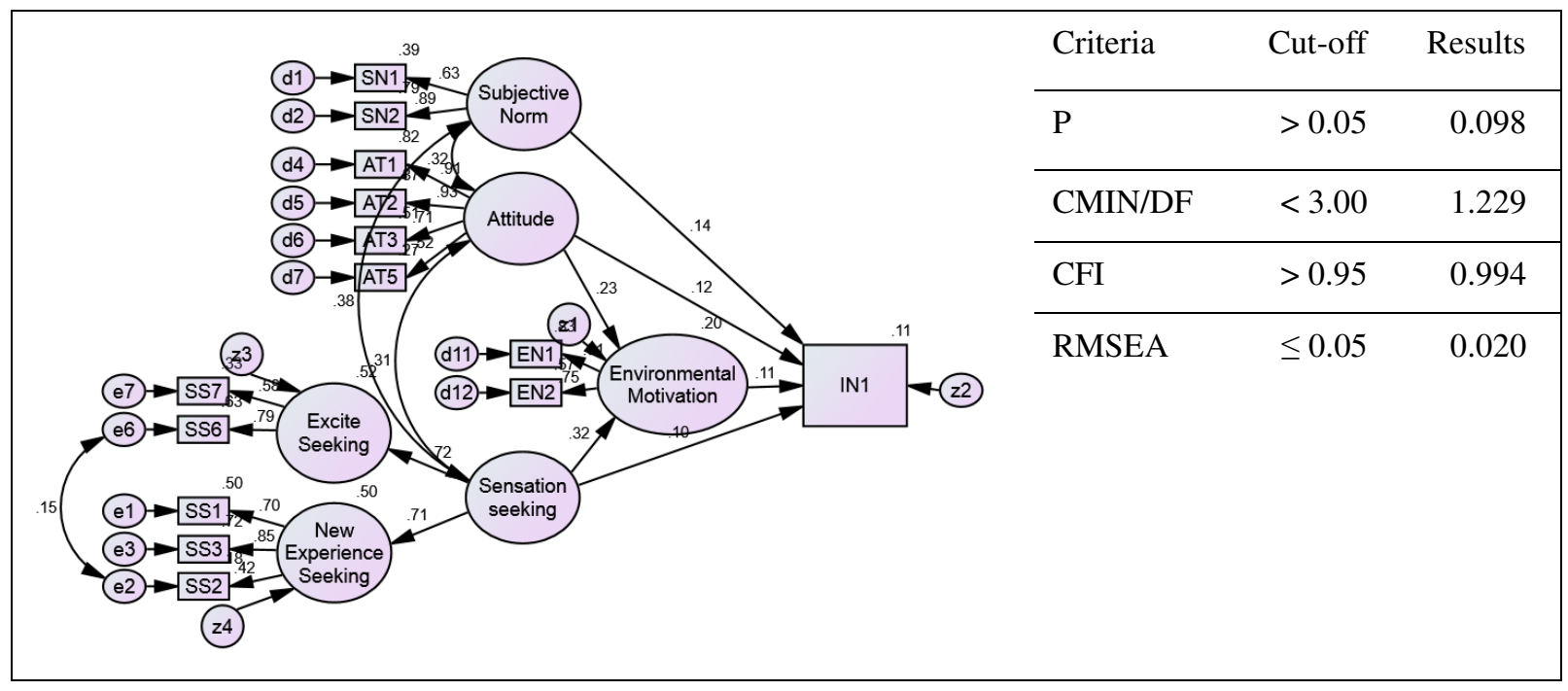

Figure 3. The fitted model to predict intention within one year

According to Holmes-Smith (2010), significance between two variables should have a score of 2.00 or greater. Observing all t-values of links in the model with intention within a year on the table below, only the link between sensation seeking personality and behavioral intention has t-value less than 2.0. These findings support previous studies as conducted by Brown (1999), Xu (2010), Hrubes et al. (2001), Jang et al. (2009), Konu and Laukkanen (2009), Shen et al. (2009), Wu and Teng (2011), and Lam and Hsu (2006). The hypothesis (H4b), 
Suhud, U.

even though has a positive and strong total effect on the relationship between those variables (Wymer Jr. et al., 2008), it should be rejected.

Table 2

Summary of hypotheses testing of the first model

\begin{tabular}{|c|c|c|c|c|c|c|c|}
\hline $\begin{array}{c}\text { Independent } \\
\text { variable }\end{array}$ & & $\begin{array}{c}\text { Dependent } \\
\text { variable }\end{array}$ & t-value & Hypothesis & Results & $\begin{array}{l}\text { Total } \\
\text { effect }\end{array}$ & Interpretation \\
\hline Subjective norms & $\rightarrow$ & $\begin{array}{l}\text { Behavioral } \\
\text { intention }\end{array}$ & 2.418 & $\mathrm{H} 1$ & Accepted & 0.292 & Mild effect \\
\hline Attitude & $\rightarrow$ & $\begin{array}{l}\text { Environmental } \\
\text { motivation }\end{array}$ & 4.355 & $\mathrm{H} 2 \mathrm{a}$ & Accepted & 0.259 & Mild effect \\
\hline Attitude & $\rightarrow$ & $\begin{array}{l}\text { Behavioral } \\
\text { intention }\end{array}$ & 2.582 & $\mathrm{H} 2 \mathrm{~b}$ & Accepted & 0.391 & $\begin{array}{l}\text { Moderately } \\
\text { strong }\end{array}$ \\
\hline $\begin{array}{l}\text { Environmental } \\
\text { motivation }\end{array}$ & $\rightarrow$ & $\begin{array}{l}\text { Behavioral } \\
\text { intention }\end{array}$ & 2.163 & H3 & Accepted & 0.263 & Mild effect \\
\hline $\begin{array}{l}\text { Sensation seeking } \\
\text { personality }\end{array}$ & $\rightarrow$ & $\begin{array}{l}\text { Environmental } \\
\text { motivation }\end{array}$ & 4.334 & $\mathrm{H} 4 \mathrm{a}$ & Accepted & 0.591 & Strong \\
\hline $\begin{array}{l}\text { Sensation seeking } \\
\text { personality }\end{array}$ & $\rightarrow$ & $\begin{array}{l}\text { Behavioral } \\
\text { intention }\end{array}$ & 1.455 & $\mathrm{H} 4 \mathrm{~b}$ & Rejected & 0.602 & Strong \\
\hline
\end{tabular}

\section{Intention within three years}

With probability score of 0.106, CMIN/DF of 1.221, CFI of 0.994, and RMSEA of 0.020 , the second fitted model was achieved to predict persons' intention to be involved in VT within three years as shown on the figure below. Two positive links were formed between: attitude and environmental motivation and sign, and attitude and intention. These findings significant with prior studies undertaken by Tsai (2010), Hrubes et al. (2001), Brown (1999), and Lam and Hsu (2006). Furthermore, three positive links were also formed between: subjective norm and intention and supported by Wu and Teng (2011), Hrubes et al. (2001), Lam and Hsu (2006); environmental motivation and intention and supported by Huang and Hsu (2009), Konu and Laukkanen (2009), and sensation seeking and intention.

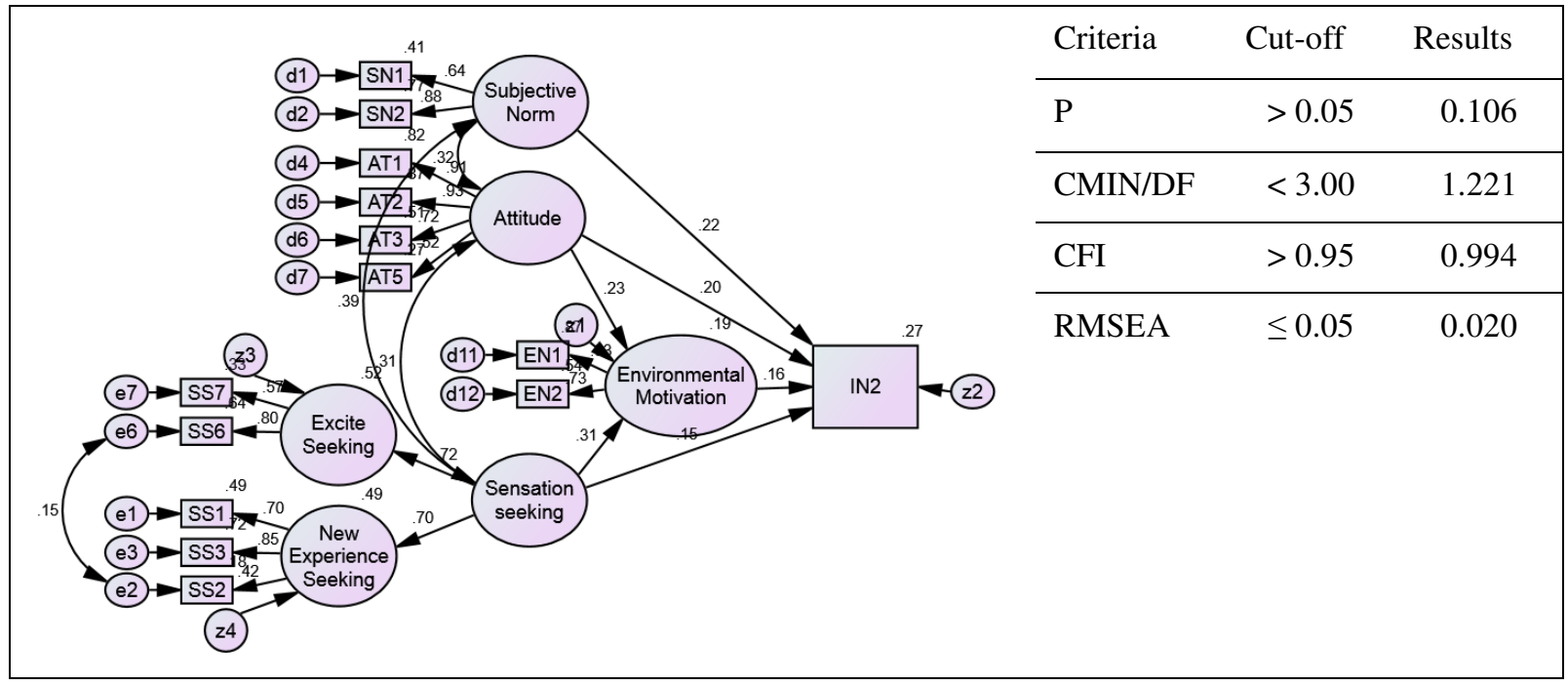

Figure 4. The fitted model to predict intention within three years

The table below shows a summary of the hypotheses testing with intention within three years. All links have t-values greater than 2.0 and each of them is positive. Therefore, the hypotheses are accepted (Holmes-Smith, 2010). These findings support the prior studies conducted by Brown (1999), Xu (2010), Hrubes et al. (2001), Jang et al. (2009), Konu and Laukkanen (2009), Shen et al. (2009), Wu and Teng (2011), Lam and Hsu (2006), and Wymer Jr. et al. (2008). 
The role of environmental motivation and sensation seeking personality to predict behavioral intention

In addition, among other links, the links between attitude and behavioral intention, and sensation seeking personality and environmental motivation have a strong total effect whereas the link between sensation seeking personality and behavioral intention has an extreme strong total effect.

Table 3

Summary of hypotheses testing of the model

\begin{tabular}{|c|c|c|c|c|c|c|c|}
\hline $\begin{array}{c}\text { Independent } \\
\text { variable }\end{array}$ & & $\begin{array}{c}\text { Dependent } \\
\text { variable }\end{array}$ & t-value & Hypothesis & Results & $\begin{array}{l}\text { Total } \\
\text { effect }\end{array}$ & Interpretation \\
\hline $\begin{array}{l}\text { Subjective } \\
\text { norms }\end{array}$ & $\rightarrow$ & $\begin{array}{l}\text { Behavioral } \\
\text { intention }\end{array}$ & 4.004 & $\mathrm{H} 1$ & Accepted & 0.480 & Moderately strong \\
\hline Attitude & $\rightarrow$ & $\begin{array}{l}\text { Environmental } \\
\text { motivation }\end{array}$ & 4.318 & $\mathrm{H} 2 \mathrm{a}$ & Accepted & 0.248 & Mild effect \\
\hline Attitude & $\rightarrow$ & $\begin{array}{l}\text { Behavioral } \\
\text { intention }\end{array}$ & 4.449 & $\mathrm{H} 2 \mathrm{~b}$ & Accepted & 0.598 & Strong \\
\hline $\begin{array}{l}\text { Environmenta } \\
1 \text { motivation }\end{array}$ & $\rightarrow$ & $\begin{array}{l}\text { Behavioral } \\
\text { intention }\end{array}$ & 3.440 & H3 & Accepted & 0.381 & Moderately strong \\
\hline $\begin{array}{l}\text { Sensation } \\
\text { seeking } \\
\text { personality }\end{array}$ & $\rightarrow$ & $\begin{array}{l}\text { Environmental } \\
\text { motivation }\end{array}$ & 4.313 & $\mathrm{H} 4 \mathrm{a}$ & Accepted & 0.576 & Strong \\
\hline $\begin{array}{l}\text { Sensation } \\
\text { seeking } \\
\text { personality }\end{array}$ & & $\begin{array}{l}\text { Behavioral } \\
\text { intention }\end{array}$ & 2.277 & $\mathrm{H} 4 \mathrm{~b}$ & Accepted & 0.872 & Extremely strong \\
\hline
\end{tabular}

\section{Intention within five years}

The third fitted model is to predict intention to be involved in VT within five years. The fitted model has probability score of 0.107 , CMIN/DF of 1.219 , CFI of 0.994 , and RMSEA of 0.020 . All links between variables are positive.

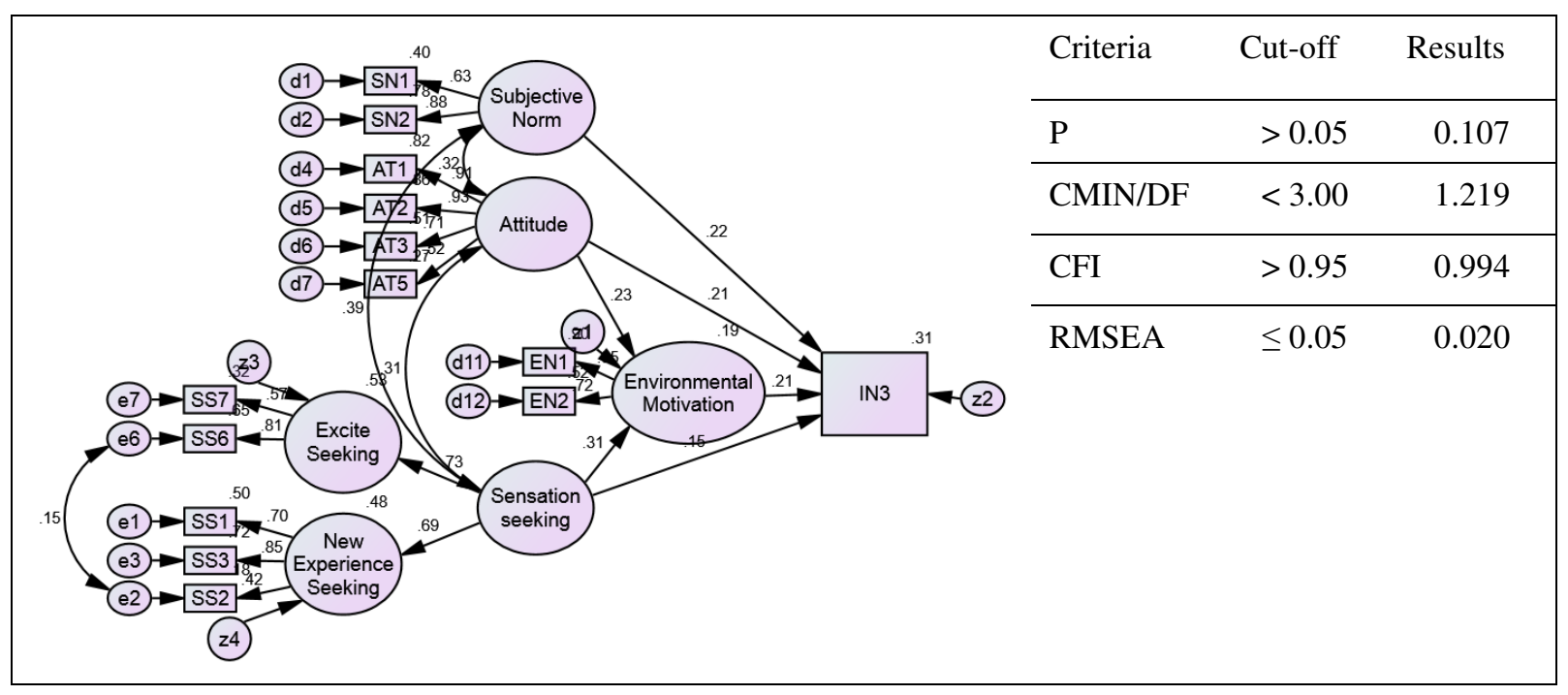

Figure 5. The fitted model to predict intention within four years

Just like the model with intention within three years, in the model with intention within five years also supports all hypotheses with the link between sensation seeking personality and behavioral intention has an extreme strong total effect. In addition, the link between attitude and behavioral intention, environmental motivation and behavioral intention, and sensation seeking personality and environmental motivation have a strong total effect. 
Suhud, U.

Table 4

Summary of hypotheses testing of the model

\begin{tabular}{|c|c|c|c|c|c|c|c|}
\hline $\begin{array}{l}\text { Independent } \\
\text { variable }\end{array}$ & & $\begin{array}{c}\text { Dependent } \\
\text { variable }\end{array}$ & t-value & Hypothesis & Results & $\begin{array}{l}\text { Total } \\
\text { effect }\end{array}$ & Interpretation \\
\hline $\begin{array}{l}\text { Subjective } \\
\text { norms }\end{array}$ & $\rightarrow$ & $\begin{array}{l}\text { Behavioral } \\
\text { intention }\end{array}$ & 4.056 & H1 & Accepted & 0.484 & $\begin{array}{l}\text { Moderately } \\
\text { strong }\end{array}$ \\
\hline Attitude & $\rightarrow$ & $\begin{array}{l}\text { Environmental } \\
\text { motivation }\end{array}$ & 4.309 & $\mathrm{H} 2 \mathrm{a}$ & Accepted & 0.241 & Mild effect \\
\hline Attitude & $\rightarrow$ & $\begin{array}{l}\text { Behavioral } \\
\text { intention }\end{array}$ & 4.743 & $\mathrm{H} 2 \mathrm{~b}$ & Accepted & 0.663 & Strong \\
\hline $\begin{array}{l}\text { Environmental } \\
\text { motivation }\end{array}$ & $\rightarrow$ & $\begin{array}{l}\text { Behavioral } \\
\text { intention }\end{array}$ & 4.679 & H3 & Accepted & 0.523 & Strong \\
\hline $\begin{array}{l}\text { Sensation } \\
\text { seeking } \\
\text { personality }\end{array}$ & $\rightarrow$ & $\begin{array}{l}\text { Environmental } \\
\text { motivation }\end{array}$ & 4.306 & $\mathrm{H} 4 \mathrm{a}$ & Accepted & 0.562 & Strong \\
\hline $\begin{array}{l}\text { Sensation } \\
\text { seeking } \\
\text { personality }\end{array}$ & & $\begin{array}{l}\text { Behavioral } \\
\text { intention }\end{array}$ & 2.352 & $\mathrm{H} 4 \mathrm{~b}$ & Accepted & 0.971 & $\begin{array}{l}\text { Extremely } \\
\text { strong }\end{array}$ \\
\hline
\end{tabular}

\section{Discussion and conclusion}

In general, from the models with intention within three and five years, almost all hypotheses were accepted. By looking at the t-value (CR-Critical Ratio), the links between subjective norm and behavioral intention are positive and significant in the three fitted models and these findings are supported by prior researchers, such as Hrubes et al. (2001), Lam and Hsu (2006), Shen et al. (2009), and Wu and Teng (2011).Therefore, H1 is accepted.

The links between attitude and environmental motivation show positive and significant in the three fitted models. As a result, H2a is accepted. These findings are correspondent with a study undertaken by Tsai (2010) Nevertheless, $\mathrm{H} 2$ is accepted. $\mathrm{H} 2 \mathrm{~b}$ is also accepted as the links between attitude and intention are positive and significant in all models. The findings correspondent with prior studies conducted by Hrubes et al. (2001), Lam and Hsu (2006), and Brown (1999); furthermore, the links between environmental motivation (in theories, only motivation) and behavioral intention are also supported as studies undertaken by Huang and Hsu (2009), Jang et al. (2009), and Konu and Laukkanen (2009). Therefore, H3 is accepted.

$\mathrm{H} 4 \mathrm{a}$ is also accepted as the links between sensation seeking personality and motivation in the three fitted models are positive and significant and supported by a prior study conducted by Xu et al. (2010). A rejection occurred on the first fitted model. The link between sensation seeking and behavioral intention had t-value of 1.455. According to Holmes-Smith (2010), the author considers any t-value that less than 2.0 as insignificant. Therefore, $\mathrm{H} 4 \mathrm{~b}$ in the first model is rejected. However, this link had total effect 0.602 that indicated a strong sensation seeking personality had a strong effect on behavioral intention. On the other hand, the links between sensation seeking personality and intention in the second and third models are positive and significant. Therefore, $\mathrm{H} 4 \mathrm{~b}$ is accepted in the second and third fitted models. The findings are correspondent with a prior study undertaken by Wymer Jr. et al. (2008).

Finally, based on the findings, it can be concluded that intention to be involved in VT is influenced by subjective norm, attitude, environmental motivation, and sensation seeking personality. This study contributes in creating another extended version of theory of reasoned action (Ajzen \& Fishbein, 1980; Fishbein \& Ajzen, 1975). Furthermore, there are different intentions within different period of time: intention within one year is influenced by subjective norm, attitude, and environmental motivation whereas intentions within three and five years are influenced by all variables used in this study.

The author recommends for future research, to apply different kind of motivation, for example taking/receiving and giving motivations (Suhud, 2013) or religious motivation to replace environmental 
The role of environmental motivation and sensation seeking personality to predict behavioral intention

motivation. Furthermore, the future research also could divide respondents from developed and developing countries. Furthermore, looking at the total effect scores, some links have mild effects, some others have moderately, strong, and extremely strong effects. (Holmes-Smith, 2010) classified the rules of thumb to interpret total effects. The effects can be considered weak if the score $<0.20$, mild if the score between 02.-0.3, moderately strong if the score between $0.3-05$, strong of the score between $0.5-0.8$, and extremely strong if the score $>0.8$.

Based on the findings, total effects of subjective norm on behavioral intention were mild within a year, and moderately strong between intention three and five years. Total effects of attitude towards environmental motivation were all mild. Furthermore, total effects of attitude on behavioral intention were moderately strong for intention within a year and strong within intention three and five years. Mild effect occurred on the link between environmental motivation and behavioral intention within a year, whereas moderately strong within three and five years. Furthermore, strong effects occurred on the link of sensation seeking personality on environmental motivation within all periods of intention. The last, total effects of sensation seeking personality and behavioral intention were strong within a year and extremely strong within three and five years. The findings have a managerial implication that VT service providers should consider environmental contents in developing VT projects.

Acknowledgement: This study was supported by Islamic Development Bank and Universitas Negeri Jakarta, Indonesia.

\section{References}

Ajzen, I., \& Fishbein, M. (1980). Understanding attitudes and predicting social behaviour. New Jersey: Prentice-Hall, Inc.

Brightsmith, D. J., Stronza, A., \& Holle, K. (2008). Ecotourism, conservation biology, and volunteer tourism: A mutually beneficial triumvirate. Biological Conservation, 141(11), 2832-2842. http://dx.doi.org/10.1016/j.biocon.2008.08.020

Broad, S., \& Jenkins, J. (2008). Gibbons in their midst? Conservation volunteers' motivations at the Gibbon Rehabilitation Project, Phuket, Thailand. In K. D. Lyons \& S. Wearing (Eds.), Journeys of discovery in volunteer tourism (pp. 72 - 85). Oxfordshire: CAB International.

Brown, T. J. (1999). Antecedents of culturally significant tourist behavior. Annals of Tourism research, 26(3), 676-700. http://dx.doi.org/10.1016/S0160-7383(99)00004-3

Bruyere, B., \& Rappe, S. (2007). Identifying the motivations of environmental volunteers. Journal of Environmental Planning and Management, 50(4), 503-516. http://dx.doi.org/10.1080/09640560701402034

Coghlan, A. (2006). Volunteer tourism as an emerging trend or an expansion of ecotourism? A look at potential clients' perceptions of volunteer tourism organisations. International Journal of nonprofit and Voluntary Sector Marketing, 11, 225-237. http://dx.doi.org/10.1002/nvsm.35

Fishbein, M., \& Ajzen, I. (1975). Belief, attitude, intention and behaviour: An introduction to theory and research: Addison-Wesley.

Franke, N., Keinz, P., \& Steger, C. J. (2009). Testing the value of customization: when do customers really prefer products tailored to their preferences? Journal of Marketing, 73(5), 103-121. http://dx.doi.org/10.1509/jmkg.73.5.103

Galley, G., \& Clifton, J. (2010). The motivational and demographic characteristics of research ecotourism: Operation Wallacea Volunteers in Southeast Sulawesi, Indonesia. journal of Ecotourism, 3(1), 69-82. http://dx.doi.org/10.1080/14724040408668150

Gray, N. J., \& Campbell, L. M. (2007). A decommodified experience? Exploring aesthetic, economic and ethical values for volunteer ecotourism in Costa Rica. Journal of Sustainable Tourism, 15(5), 463-482. http://dx.doi.org/10.2167/jost725.0 
Suhud, U.

Greenslade, J. H., \& White, K. M. (2005). The prediction of above-average participation in volunteerism: A test of the theory of planned behaviour and the volunteer functions inventory in older Australian adults. The Journal of Social Psychology, 145(2), 155-172. http://dx.doi.org/10.3200/SOCP.145.2.155-172

Han, H., Lee, S., \& Lee, C. K. (2011). Extending the theory of planned behavior: Visa exemptions and the traveller decision-making process. Tourism Geographies, 13(1), 45-74. http://dx.doi.org/10.1080/14616688.2010.529930

Hobbs, G. (2007). Hands-on holidays. Charitable trips, rewarding adventures, volunteer breaks. Richmond: Crimson Publishing.

Holmes, T. J., \& Yan, R. (2012). Predicting consumers' preferences for and likely buying of local and organic produce: Results of a choice experiment. Journal of Food Products Marketing, 18(5), 369-384. http://dx.doi.org/10.1080/10454446.2012.685029

Holmes-Smith, P. (2010). Structural equation modeling: From the fundamentals to advanced topics. Melbourne: SREAMS (School Research Evaluation and Measurement Services)

Hrubes, D., Ajzen, I., \& Daigle, J. (2001). Predictiong hunting intentions and behaviour: An application of the theory of planned behaviour. Leisure Sciences, 23(3), 165-178. http://dx.doi.org/10.1080/014904001316896855

Huang, S., \& Hsu, C. H. C. (2009). Effects of travel motivation, past experience, perceived constraint, and attitude on revisit intention. Journal of Travel Reseach, 48, 29-44. http://dx.doi.org/10.1177/0047287508328793

Jang, S., Bai, B., Hu, C., \& Wu, C. E. (2009). Affect, travel motivation, and travel intention: A senior market. Journal of Hospitality \& Tourism Research, 33, 51-73.

Juster, F. T. (1966). Consumer buying intentions and purchase probability: An experiment in survey design. Journal of the American Statistical Association, 658-696. http://dx.doi.org/10.1080/01621459.1966.10480897

Kerr, G., Cliff, K., \& Dolnicar, S. (2012). Harvesting the "Business Test Trip": Converting business travelers to holidaymakers. Journal of Travel \& Tourism Marketing, 29(5), 405-415. http://dx.doi.org/10.1080/10548408.2012.691390

Konu, H., \& Laukkanen, T. (2009). Roles of motivation factors in predicting tourists' intentions to make wellbeing holidays - a Finnish case. Paper presented at the Australian New Zealand Marketing Academy 2009, Melbourne.

Lam, T., \& Hsu, C. H. C. (2006). Predicting behavioral intention of choosing a travel destination. Tourism Management, 27, 589-599. http://dx.doi.org/10.1016/j.tourman.2005.02.003

Nguyen, C., \& Romaniuk, J. (2012). Factors moderating the impact of word of mouth for TV and film broadcasts. Australasian Marketing Journal (AMJ). http://dx.doi.org/10.1016/j.ausmj.2012.08.004

Raymond, E. (2008). 'Make a difference!': The role of sending organisations in volunteer tourism. In K. D. Lyons \& S. Wearing (Eds.), Journeys of Discovery in Volunteer Tourism (pp. 49-60). Lindfield: CABI Publishing.

Shen, S., Schuttemeyer, A., \& Braun, B. (2009). Visitors' intention to visit world cultural heritage sites: An empirical study of Suzhou, China. Journal of Travel \& Tourism Marketing, 26(7), 722-734. http://dx.doi.org/10.1080/10548400903284610

Suhud, U. (2013). Taking/receiving and giving (TRG): A mixed-methods study to examine motivations in volunteer tourism. Paper presented at the International Conference on Hospitality and Tourism Management-2013, Colombo.

Suhud, U. (2014). A moment to give, no moment to take: A mixed-methods study on volunteer tourism marketing: Lap Lambert Academic Publishing.

Tourism Research and Marketing. (2008). Volunteer tourism: A global analysis. Barcelona: Association for Tourism and Leisure Education (ATLAS).

Tsai, C. (2010). The physical disabilities' travel behaviours. African Journal of Business Management, 4(1), $512-525$.

Van der Meer, K. (2007). Persepectives on ecotourism and volunteer tourism in post tsunami Khao Lak, 
The role of environmental motivation and sensation seeking personality to predict behavioral intention

Thailand. University of Victoria Retrieved from http://dspace.library.uvic.ca:8080/handle/1828/2529

Wearing, S. (2001). Volunteer tourism. Experiences that make a difference. Wallingford: CAB International. http://dx.doi.org/10.1079/9780851995335.0000

Wu, K.-S., \& Teng, Y. M. (2011). Applying the extended theory of planned behavior to predict the intention of visiting a green hotel. African Journal of Business Management, 5(17), 7579-7587.

Wymer Jr., W. W., Self, D. R., \& Findley, C. S. C. (2008). Sensation seekers and civic participation: Exploring the influence of sensation seeking and gender on intention to lead and volunteer. International Journal of Nonprofit and Voluntary Sector Marketing, 13(4), 287-300. http://dx.doi.org/10.1002/nvsm.330

Wymer Jr., W. W., Self, D. R., \& Findley, C. S. C. (2010). Sensation seekers as a target market for volunteer tourism. Service Marketing Quarterly, 31(3), 348-362.

http://dx.doi.org/10.1080/15332969.2010.486698

$\mathrm{Xu}, \mathrm{S}$. (2010). Motivations and sensation seeking behind recreational storm chasers in the United States. University of Missouri, Missouri.

Xu, S., Stanis, S. W., Barbieri, C., \& Chen, J. (2010). Motivations and sensation seeking characteristics of recreational storm chasers. Paper presented at the 2010 Northeastern Recreation Research Symposium. 
Suhud, U. 